\title{
Indirect immunofluorescence test for the detection of Aspergillus fumigatus antibodies
}

\author{
D. W. WARNOCK \\ From the Pathology Department, Bristol Royal Infirmary, Bristol BS2 $8 \mathrm{HW}$
}

SYNOPSIS An indirect immunofluorescence test was both sensitive and specific in detecting IgG antibodies to Aspergillus fumigatus. The test revealed a significant increase in titre of antibodies in patients with the allergic or mycetomal forms of pulmonary aspergillosis.

The demonstration of precipitating antibodies to Aspergillus fumigatus is of importance in the diagnosis of the different clinical manifestations of aspergillosis. The principal serological method at present used to detect these antibodies is the double diffusion test. Immunofluorescence is a sensitive method which has been used to detect circulating antibodies in persons with mycotic infections including coccidioidomycosis, cryptococcosis, and histoplasmosis (Kaplan, 1970). This paper presents evidence of the value of the indirect immunofluorescence test in the diagnosis of the allergic and mycetomal forms of pulmonary aspergillosis.

\section{Methods}

\section{SUBJECTS}

Serum specimens used in this investigation were obtained from 15 persons with clinical and mycological evidence of pulmonary aspergillosis due to Aspergillus fumigatus; five persons with blastomycosis; five persons with disseminated candidiasis; five persons with coccidioidomycosis; one person with cryptococcosis; five persons with histoplasmosis; and from 20 normal human subjects.

\section{PREPARATION OF ANTIGEN}

Slide cultures of Aspergillus fumigatus were prepared according to the method of Riddell (1950). After incubation for $48 \mathrm{hr}$ at $37^{\circ} \mathrm{C}$, the mycelium adhering to the slides was treated with acetone for 20 minutes.

\section{IMMUNOFLUORESCENCE TEST}

The clinical status pertaining to each serum specimen was not known when the immunofluorescence test was performed.

Received for publication 22 August 1974.
Doubling dilutions of serum from 1:10 were made in phosphate-buffered saline $\mathbf{p H ~} 7 \cdot 1$. One dilution of serum was placed on each antigen preparation. These were incubated for $30 \mathrm{~min}$ at $37^{\circ} \mathrm{C}$ in a humid chamber before being rinsed in two changes of buffered saline for $5 \mathrm{~min}$ each. Fluorescent antihuman IgG (Wellcome) was placed on each preparation and left for $30 \mathrm{~min}$ at $37^{\circ} \mathrm{C}$. Each preparation was again rinsed in two changes of buffered saline for 5 min each and then mounted in buffered glycerol.

In addition to the serum under investigation, preparations treated with negative or positive human serum and then with fluorescent antihuman globulin were included on each occasion. The essential criterion of positive immunofluorescence was the bright green fluorescence of the hyphal walls. Tests with untreated mycelium and with mycelium treated with fluorescent antihuman globulin alone did not give this distinctive fluorescence. The highest dilution of each serum which gave definite cell wall fluorescence was taken as the endpoint for that serum. Observation of the gradual fading of the fluorescence with increasing dilution of the serum helped in determining the endpoint and in cases of doubt, the test was repeated.

\section{Results}

The table summarizes the titre of IgG antibodies to Aspergillus fumigatus in serum specimens from the 56 subjects tested. The 21 persons with mycotic infections other than aspergillosis and the 20 normal persons had titres of $1: 10$ or $1: 20$. Titres of $1: 80$ were therefore considered to be significant. Titres in the patients with aspergillosis varied from $1: 80$ or $1: 160$ in nine persons with the allergic form to $1: 160$ or more in six persons with the mycetomal form. 


\begin{tabular}{|c|c|c|c|c|c|c|}
\hline \multirow[t]{2}{*}{ Diagnosis } & \multirow[t]{2}{*}{ Total } & \multicolumn{3}{|c|}{$\begin{array}{l}\text { Number of Persons } \\
\text { titre of }\end{array}$} & \multicolumn{2}{|c|}{ with an Anti-aspergillu } \\
\hline & & $\ll 1: 20$ & $1: 40$ & $1: 80$ & $1: 160$ & $1: 320$ \\
\hline $\begin{array}{l}\text { Allergic } \\
\text { aspergillosis } \\
\text { Mycetomal }\end{array}$ & 9 & 0 & 0 & 8 & 1 & 0 \\
\hline $\begin{array}{r}\text { aspergillosis } \\
\text { Other mycotic }\end{array}$ & 6 & 0 & 0 & 0 & 2 & 4 \\
\hline $\begin{array}{l}\text { infection } \\
\text { Normal }\end{array}$ & $\begin{array}{l}21 \\
20\end{array}$ & $\begin{array}{l}21 \\
20\end{array}$ & $\begin{array}{l}0 \\
0\end{array}$ & $\begin{array}{l}0 \\
0\end{array}$ & $\begin{array}{l}0 \\
0\end{array}$ & $\begin{array}{l}\mathbf{0} \\
\mathbf{0}\end{array}$ \\
\hline
\end{tabular}

Table Titre of IgG antibodies to Aspergillus fumigatus in serum from persons with aspergillosis, persons with other mycotic infections, and from normal persons

\section{Discussion}

This investigation demonstrates that most persons possess IgG antibodies to antigenic determinants of Aspergillus fumigatus. However, when patients with pulmonary aspergillosis were compared with normal persons and persons with other mycotic infections, all these patients were found to have increased IgG titres.

There would seem to be a definite relationship between the fluorescence titre of these IgG antibodies and the form of aspergillosis involved. Patients with allergic aspergillosis were found to have lower IgG titres than patients with the mycetomal form. This is consistent with reports of smaller amounts of precipitating antibodies in serum from individuals with allergic aspergillosis (Henderson, English, and Vecht, 1968; Coleman and Kaufman, 1972). The lower IgG titres in these persons may also be secondary to treatment with corticosteroids (Stevens, Russchen, Hilvering, and Orie, 1970).

The indirect immunofluorescence test employed in this investigation to estimate IgG antibodies to Aspergillus fumigatus showed significant differences $(\mathrm{P}<0.001)$ between uninfected persons and persons with different forms of pulmonary aspergillosis. Further experience with this test procedure will be required if its full clinical usefulness is to be determined but it has potential diagnostic applications in aspergillosis.

I am indebted to Dr L. Kaufman for providing some of the serum used in this investigation.

References

Coleman, R. M., and Kaufman, L. (1972). Use of the immunodiffusion test in the serodiagnosis of aspergillosis. Appl. Microbiol., 23, 301-308.

Henderson, A. H., English, M. P., and Vecht, R. J. (1968). Pulmonary aspergillosis. Thorax, 23, 513-518.

Kaplan, W. (1970). The fluorescent antibody technique in the diagnosis of mycotic diseases. In International Symposium on Mycoses, pp. 86-95. Pan American Health Organisation, Washington D.C.

Riddell, R. W. (1950). Permanent stained mycological preparatio $f$ obtained by slide culture. Mycologia, 42, 265 .

Stevens, E. A. M., Russchen, C. J., Hilvering, C., and Orie, N. G. ND (1970). Steroid effect on Aspergillus antibodies. Scand. J. resp. Dis., 51, 55-60. 